\title{
アルミニウム-亜鉛混合水酸化物含漫沪紙濃縮/
}

\section{吸光光度法による微量アニオン 界面活性剤の定量}

\author{
(1990 年 7 月 5 日 受理) \\ 石 野三三枝*·宗 森 信**
}

メンブランフィルターホルダーに, メンブランの代りにアルミニウムと亜鉛との混合水酸化物を含浸 した汇紙をはさみ，検水を汇過することにより汇紙に濃縮する。汇紙上に吸着捕集されたアニオン界面 活性剤をローダミンBと反応させ赤紫色に呈色させる。水洗によって余分のローダミンBを除去したの ち，汇紙をエタノールに抽出し抽出液の吸光度を測定してアニオン界面活性剤を定量することがでさ た。鉄(III)，カルシウム，リン酸は妨害するが，小量の塩化亜鉛を添加し，カチオン交換樹脂とともに かきまぜることによってこれらの妨害を除去できた。試料水 $50 \mathrm{ml}$ を使用した場合に最低で $0.02 \mathrm{ppm}$ までのドデシルベンセンンスルホン酸 (DBS) を定量できた。河川水中のアニオン界面活性剂の定量に応 用した。

\section{1 楮 言}

フニオン界面活性郕は工業的に各方面で使用される以外に家庭 用洗剂として日常使用されるものであるため，環境中に広く拡散 していると考えられる。したがって，その简単で安全な分析方法 が望まれる。最も一般的な分析法はメチレンブルー法"である。 これはアニオン界面活性戍がィチレンブルーとつくる複合体をク ロロホルムで抽出する方法であるか，抽出率が低いので，抽出溶

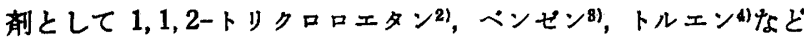
を用いる方法が報告されている。いずれにしても有機溶媒を使う 点に難点がある。

著者らはすでにアルミニウムー亜鉛混合水酸化物にアニオン界 面活性郕が注注 $100 \%$ 共沈することを報告らし，これを利用して フルミニウムー亜鉛混合水酸化物を含漫した汇紙上でフニオン界 面活性剤をローダミンBを発色試薬としてはん点分析する方法を 報告しだ)。その際，赤紫色のはん点をエタノールに抽出するこ とによって吸光光度定量が可能であることを示したが，本報はこ れを改良してさらに低漕度のアニオン界面活性郕を精度よく定㫣 することを目的としたものである。用いる有機溶媒は人体への影

岐皋大学教育学部，501-11 岐鼻市柳戸

** 631 奈良市朝日町

1) JIS K 0102 (1974).

2) 大㮛 胃, 平山光衛, 半谷高久, 内海 唋, 日化, 85,335 (1964).

3) W. A. Moore, R. A. Kolbeson, Anal. Chem., 28, 161 (1956).

4) S. Motomizu, S. Fujiwara, A. Fujiwara, K. Toei, Anal. Chem., 54, 392(1982).

5）石野二三枝, 宗林 僧, 日化, 1988, 1026.

6）石野三三枚，宗森 傮，日化，1990，848.
響が樶も少ないものであり，簡単な方法で環境水中のアニオン界 面活性剤の定鿷が可能であった。

\section{2 英験}

\section{1 装 置}

榆水の汇過には東洋汇紙製のガラスフィルターホルダー, KG$13 \mathrm{~A}$ ，容昷 $100 \mathrm{ml}$ ，汇過面䅪 $1.2 \mathrm{~cm}^{2}$ ，を用いた。

吸光度の测定には日立ダブルビーム 100-50 型, 光路長 10 $\mathrm{mm}$ ，のセルを用いた。

\section{2 試 蒋}

アニオン界面活性剤標準液として用いたドデシルベンゼンスル ホン酸ナトリウム(以下 DBS と略記する)水溶液, 塩化アルミニ ウム水溶液, 塩化正鈆水溶夜, $500 \mathrm{ppm}$ ローダン B発色試莱 (pH 5.5)，エタノールは既報尚にしたがって調製した。

カチオン交換樹脂は Dowex $50 \mathrm{~W}-\mathrm{X} 8,50 \sim 100$ メッシュ, H 型を用いた。

汇紙は東渄汇紙製 NO $65 \mathrm{~K}$ を裁断して用いた。 その他の武薬は試薬特級品を用いた。

2.3 アルミニウム-亜鉛混合水酸化物含漫沪紙（以下含漫沪紙 と略款する) の作製

$0.5 \mathrm{~mol} \cdot \mathrm{dm}^{-8}$ の塩化亚鉛と $0.3 \mathrm{~mol} \cdot \mathrm{dm}^{-8}$ の塩化アルミニウ

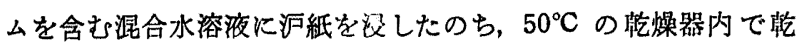
煤した。䔮燥洰紙を $1 \mathrm{~mol} \cdot \mathrm{dm}^{-3}$ 水酸化ナトリウム溶液に浸し， すぐに引き上げ轮燥し，再び水酸化ナトリウム溶液に浸す操作を 3 回くり返した。最後に虼燥した沪紙を流水中で 2,3 分間洗消

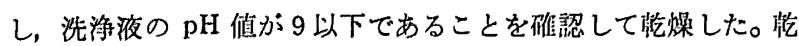
燥した含漫汇紙を $2 \mathrm{~cm} \times 2 \mathrm{~cm}$ に阵断し保存した。

2.4 操 作 含漫沪紙をガラスフィルターホルダーにはさみ，DBS 試料液 
$50 \mathrm{ml}$ を 20〜30 分間で沪過したのち数 $\mathrm{ml}$ の蒸留水でホルダー の内壁をていねいに洗った。この洗浄水も沪過したのち，最後に 数秒間吸引した。この含浸汇紙をローダミンB発色試薬に浸して 発色させたのち，30 分間水洗して余分のローダミンBを除いた。 含漫汇紙上の赤紫色呈色部分を切り取って $10 \mathrm{ml}$ の共栓付き試験 管に入れ，エタノール $2 \mathrm{~m} l$ を加えてよくふり赤色の抽出液を得 た。この抽出液の $545 \mathrm{~nm}$ に扣ける四光度を测定し，同様にして 得た陚薬空試験値との差を用いて，あらかじめ作成しておいた愉 量線より DBS を定量した。

\section{3 結 果 と考察}

\section{1 含渻洰紙の作製}

No. 2 の汇紙を用いた含漫沪紙(6)では， $50 \mathrm{ml}$ の試料液を取り扱 った場合に赤紫色の呈色が含浸汇紙の䇎面にまで達しておうり， DBS を完全に捕集することができなかった。そこで沪紙の種頑 として最も厚く，汇過速度の速い東洋汇紙製の NO $65 \mathrm{~K}$ を選ん た。前報6) と同じように，路独の水酸化アルミニウムおよび水酸 化亜鉛を含浸した各汇紙上に DBS はそれぞれ 50\% および $40 \%$ しか捕集しなかったが，混合した場合には捕集率は上昇し，亚鉛 の混合比が 40〜80\% の簛囲内においてほぼ 100\% 捕集した。 等モルの塩化アルミニウムと塩化亜鉛との混合溶液を用いて含浸 汇紙をつくった場合，濼度がそれぞれ $0.1 \mathrm{~mol} \cdot \mathrm{dm}^{-3}$ 以下では DBS の捕集は不完全であり, $0.6 \mathrm{~mol} \cdot \mathrm{dm}^{-3}$ 以上では沪過所要時 間が 2 洔間以上となり，かなり多冝の陚料液が汇紙の側面から漫 出して漏斗のすきまから流出した。そのためはん点は不鮮明とな り，抽出液の四光度も低值を示した。混合比と滥度とを種々変化 させて検討した絬果, 塩化アルミニウムについて $0.3 \mathrm{~mol} \cdot \mathrm{dm}^{-3}$, 塩化亜鈶について $0.5 \mathrm{~mol} \cdot \mathrm{dm}^{-3}$ の混合溶液が掫適であった。水 酸化物生成に用いる水酸化ナトリウム溶液の灌度についての詳細 な検討はしなかったが，金属塩化物を含漫した沪紙を水酸化ナト リウム溶液に浸して放着すると金属イオンが溶出し，水溶液中で 水酸化物の沈殷を生した。したがって，十分に乾燥した沪紙を短 時間水酸化ナトリウム溶液に浸し，これをくり返して混合水酸化 物含漫汇紨を作留した。

\subsection{DBS 試料液の $\mathrm{pH}$}

$\mathrm{pH}$ 值を 3 から 11 まで変化させた DBS 試料液を用いて実騟 を行い, 試料液の $\mathrm{pH}$ 变化による捕集率の変化を検討した。図 1 に示すように pH 4.8〜5.5 の筑罒内で捕集率はほぼ 100\%であ った。 $\mathrm{pH} 6$ 以上では捕集率は再び下降し $\mathrm{pH} 8$ まではかなりの

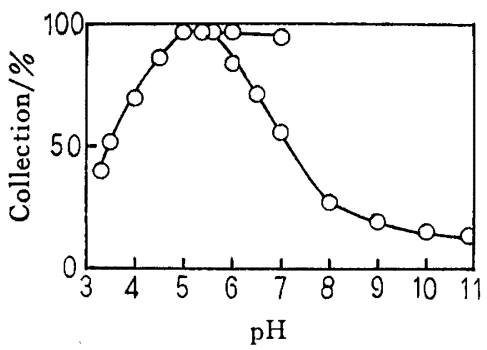

Fig. 1 Collection of dodecylbenzenesulfonate (DBS) on filter paper impregnated with mixed hydroxide of aluminum and zinc as a function of $\mathrm{pH}$

DBS : $0.4 \mathrm{ppm}$

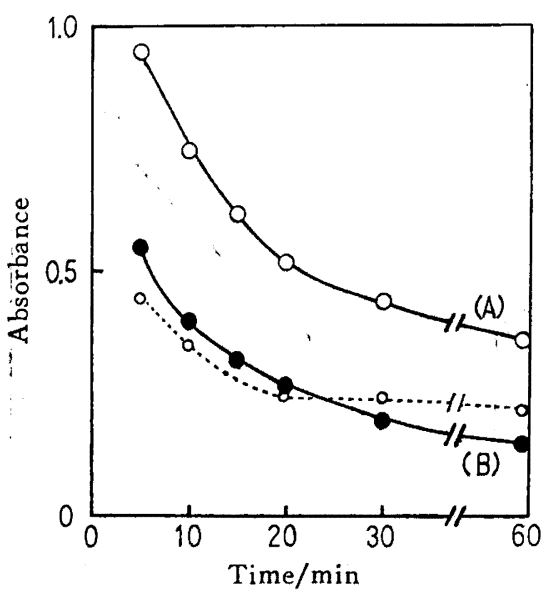

Fig. 2 Washing out of excess Rhodamine $B$ from filter paper impregnated with mixed hydroxide of aluminum and zinc

(A): In the presence of DBS

(B): In the absence of DBS (blank)

-- O---: Difference between $A$ and $B$

ばらつきを生じた。DBS 陚料液の $\mathrm{pH}$ は 5.0〜5.3 の範囲内と した。

\section{3 呈色沪紙の水洗時间}

DBS を捕集した含漫沪紙をローダミンB水溶液に浸して発色 させるので，このとき沪紙住分付付着するローダミンBを水洗 によって除去する方法を検討した。100 $\mathrm{ml}$ のビーカーに水道水を 満たし,この中に発色直後の含漫沪紙 1 枚を入れ， 5 分間扣きに水 を入れ替えながら放䑄した。DBS が存在する場合には汇紙から

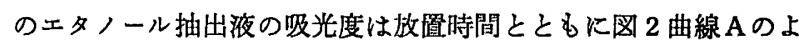
らに変化した。一方，DBS が存在しないとき，すなわち空試験で は曲線Bのように変化した。両曲線の差は点線で示すように20 分間経過すると一定の值となったため水洗時間を 30 ～35 分間と した。

\section{4 : 検 量 線}

種々の置の DBS を含む試料液 $50 \mathrm{~m} l$ を用いて検量線を作成し た。図 3 に示すように, $0.02 \mathrm{ppm}$ から $1.0 \mathrm{ppm}$ までで直線珄は 成立した。0.2 ppm DBS 試料液についての 7 回くり返し測定の 変㔚係数は $5.5 \%$ であった。

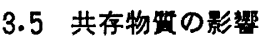

環境水中に溶存する物質とメチレンブルー法に影響を与える物 質を考應して 15 種類の物質を選び，その举動について検討した。 結果を表 1 亿示す。メチレンブルー法に干涉する有機物はほとん ど影響しなかったが，環境水中にはかならず共存する鉄(四)，力 ルシウム, リン酸の影響はいちじるしかったので, その除去につ いて榆討した。

\section{6 妨客物酤の除去}

図 4 の曲線Aに示すように，鉄(III)，カルシウム、リン酸はそ れぞれ低浱度です妨害した。これらのらちカチオンを除去する目 的でカチオン交換樹脂を試料液に添加してかきまぜたが，曲線 B に示すように，剑(III) とカルシウムの放害を除去するには，効果 がなかった。一方, リン酸イオンは混合水酸化物の成分のひとつ の巠鉛イオンと難溶性塩をつくることを利用して，亚鉛イオンの 


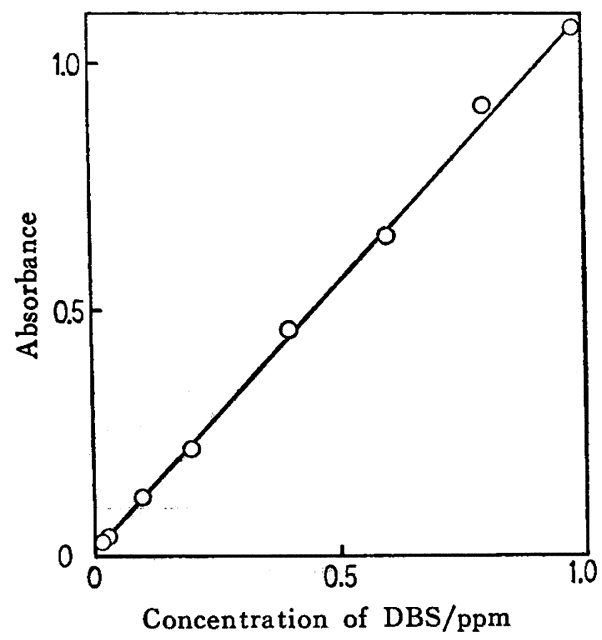

Fig. 3 Calbration curve for DBS

Sample taken : $50 \mathrm{~m} l$

Table 1 Effect of foreign substances on recovery of DBS

\begin{tabular}{lccc} 
Substance & Added as & $\begin{array}{c}\text { Concentration of } \\
\text { foreign substance } \\
(\mathrm{ppm})\end{array}$ & $\begin{array}{c}\text { Recovery } \\
(\%)\end{array}$ \\
\hline $\mathrm{Mn}^{2+}$ & $\mathrm{MnCl}_{2}$ & 0.2 & 100 \\
$\mathrm{Cu}^{2+}$ & $\mathrm{CuCl}_{2}$ & 0.2 & 57 \\
$\mathrm{Fe}^{2+}$ & $\mathrm{FeCl}_{2}$ & 0.2 & 80 \\
$\mathrm{Fe}^{8+}$ & $\mathrm{FeCl}_{3}$ & 0.2 & 15 \\
$\mathrm{Ca}^{2+}$ & $\mathrm{CaCl}_{2}$ & 10 & 80 \\
$\mathrm{CrO}_{4}{ }^{2-}$ & $\mathrm{K}_{2} \mathrm{CrO}_{4}$ & 0.2 & 83 \\
$\mathrm{~S}^{2-}$ & $\mathrm{Na}_{2} \mathrm{~S}^{-}$ & 1 & 79 \\
$\mathrm{CN}^{-}$ & $\mathrm{KCN}$ & 1 & 85 \\
$\mathrm{PO}_{4}{ }^{8-}$ & $\mathrm{Na}_{2} \mathrm{HPO}_{4}$ & 1 & 56 \\
$\mathrm{SO}_{4}{ }^{2-}$ & $\mathrm{Na}_{2} \mathrm{SO}_{4}$ & 1 & 85 \\
Lysine & & 1 & 98 \\
Urea & & 1 & 102 \\
Gultamic & & 1 & 93 \\
acid & & 1 & 84 \\
Gelatin & & 1 & 100 \\
Cystine & & &
\end{tabular}

DBS : $0.4 \mathrm{ppm}$.

添加によってリン酸イオンを除去しようとしたが，別の実験によ って亜鉊イオンも過剩に共存すると妨害することが明らかとなっ たため，亜鉛イオンとともにカチオン交換樹脂を添加してかきま ぜたところ，曲線（C）に示すよらにほぼ 100\% 妨害を除去する ことができた。同じ操作によって鉄(III) とカルシウムの妨害を 除去することができた。その理由は明らかでない。既報阳におい て DBS を吸着捕集したはん点部分が水をはじく現象はDBSの 親水基がフルミニウム-亜鉛混合水酸化物側に, 疎水基が外側に 配向して密に吸着捕集しているためと考えられる。本報に拈ける DBS 試料夜は函低濃度であるため水をはじく現象は認められな いが，同様にして親水基側でフルミニウムー亜鉛混合水酸化物に 捕集されるのであろう。鉄(III), カルシウムが共存した場合, こ れらは DBS と錯体を形成して捕集を妨害し, 添加した亜鉛はこ の鉄(III)，カルシウムと直換し捕集されると思われる。

環境水中のアニオン界面活性剤定量のための前処理として以下

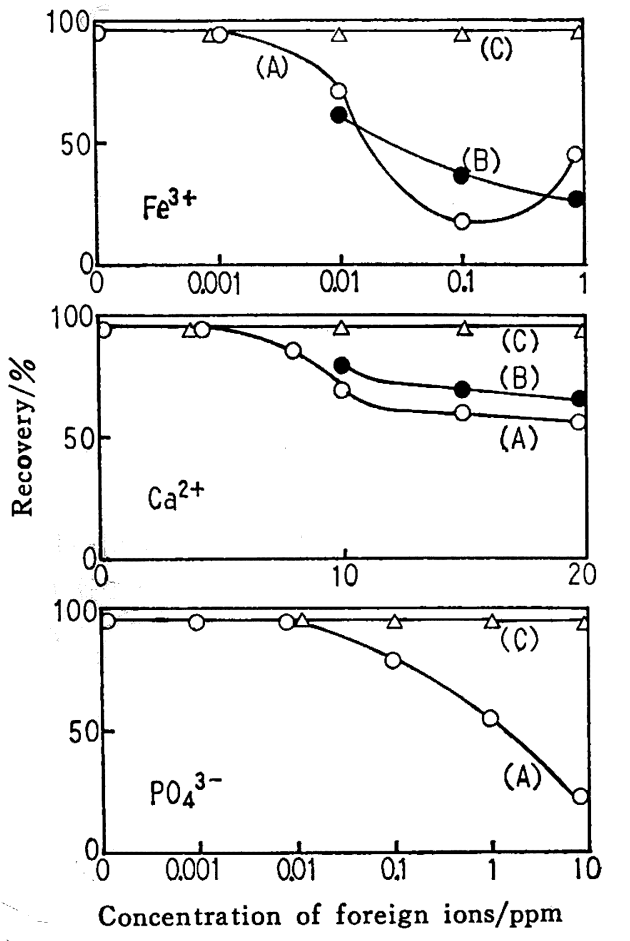

Fig. 4 Effect of divers ions

(A): In the presence of $\mathrm{Fe}^{8+}, \mathrm{Ca}^{2+}$ or $\mathrm{PO}_{4}{ }^{3-}$

(B) : Sample solution was stirred with cationexchanger added

(C) : Sample solution was stirred with zinc chloride and cation-exchanger added

DBS : $0.4 \mathrm{ppm}$

Table 2 Recovery of added DBS in river water

\begin{tabular}{lccc} 
Sample & $\begin{array}{c}\text { Added } \\
(\mathrm{ppm})\end{array}$ & $\begin{array}{c}\text { Found } \\
(\mathrm{ppm})\end{array}$ & $\begin{array}{c}\text { Recovery } \\
(\%)\end{array}$ \\
\hline Ijira river & 0 & 0.02 & \\
Kurifunebashi & 0.2 & 0.21 & 95 \\
Shinbori river & 0 & 0.06 & \\
Daigakubashi & 0.2 & 0.28 & 110 \\
Shinbori river & 0 & 0.16 & \\
Shiborinigoukyou & 0.2 & 0.34 & 90
\end{tabular}

Sample taken : $50 \mathrm{~m} l$.

の操作を行った。環境水を $0.45 \mu \mathrm{m}$ メンブランフィルターで沪 過したのち，その $250 \mathrm{ml}$ にカチオン交換樹脂（H型）を見かけ の容積で $3 \mathrm{~m} l$ 添加し, $\mathrm{pH}$ が最低值となるまでかきまぜた。傾 斜法によって得た上澄み液に $3 \mathrm{~mol} \cdot \mathrm{dm}^{-3}$ 塩化重鉛溶液 $100 \mu l$ を 添加して 10 分間かきまぜた。再び，カチオン交換樹脂（H型） $2 \mathrm{~m} l$ を添加して 10 分間かきまぜた。傾斜法によって得た上澄み 液の $\mathrm{pH}$ 值を $5.0 \sim 5.3$ の範囲内に調節して検水とした。

\section{7 実試料への応用}

岐阜大学柳戸地区の東側と西側を流れる伊自良川と新堀川から 採取した水の中のアニオン界面活性剤をDBS と見なし，標準添 加法によって定量した。結果を表 2 に示す。DBS の回収率は 90〜 100\% であり， 7 回のくり返し測定の変動係数は 8.6\% であ った。 


\title{
Determination of Trace Amounts of Anionic Surfactants by Spectrophotometry After Preconcentration on Paper Impregnated with Mixed Hydroxide of Aluminum and Zinc
}

\author{
Fumie Ishino* and Makoto Munemori** \\ Faculty of Education, Gifu University: Yanagido, Gifu-shi 501-11 Japan \\ ** Asahi-cho, Nara-shi 631 Japan
}

\begin{abstract}
A simple and rapid method for the determination of trace amounts of anionic surfactants was proposed. When a sample solution was filtered through a filter paper impregnated with mixed hydroxide of aluminum and zinc, anionic surfactants were collected on the filter paper as reddish violet products given by the reaction with Rhodamine B. The paper was washed with water to remove excess reagents and extracted with ethyl alcohol. The absorbance of the extract was measured. Interference from iron(III), calcium and phosphate could be avoided by the addition of a small amount of zinc chloride and cation-exchange resin. Dodecylbenzenesulfonate as low as $0.02 \mathrm{ppm}$ could be determined. The method was applied to the river water.
\end{abstract}

